[Short Report]

\title{
Effects of Transitory Stimulation Interval Exercise on Physical Function: A Randomized Controlled Pilot Study among Japanese Subjects
}

Yasumasa Eguchi*, Masanori Ohta, Tomohiro Inoue, Toru Honda, Yusaku Morita, Yoshimasa KonNo and Hiroshi YAMATO

Department of Health Development, Institute of Industrial Ecological Sciences, University of Occupational and Environmental Health. Yahatanishi-ku, Kitakyushu 807-8555, Japan

Abstract : Interval training is effective for promoting aerobic capacity and general health. However, it involves repeated high-intensity activity, which could pose cardiovascular risks for the elderly or people who are less fit. We developed a transitory stimulation interval exercise (TSIE) in which the duration of strenuous exertion was reduced to 30 seconds at $75 \%$ $\dot{\mathrm{V}}_{2}$ max of intensity. This pilot study aims to explore the effects of this mode of exercise. Thirty women were randomized and stratified into the TSIE group, the continuous moderate exercise (CME) group, or the no-exercise (NE) group. The two exercise groups performed exercises for 12 weeks. Significant positive changes were observed in the TSIE group compared with the NE group in the relative change ratio from baseline in body weight and $\dot{\mathrm{V}}_{2}$ max, but no significant differences were observed between the CME group and the NE group. Glycated hemoglobin A1c (HbAlc) decreased significantly in both exercise groups compared with the NE group. Overall, there were few significant differences between the CME group and the TSIE group. There might not be any differences between the TSIE and the $\mathrm{CME}$ in a long term intervention with equalized training volumes.

Key words : transitory stimulation, interval exercise, oxygen uptake, randomized controlled trial, health promotion.

(Received August 8, 2012, accepted November 20, 2012)

*Corresponding Author: Yasumasa EGUCHI, Department of Health Development University of Occupational and Environmental Health, Japan. 1-1 Iseigaoka, Yahatanishi-ku, Kitakyushu 807-8555, Japan Tel: +81-93-691-7473, Fax: +81-93-6026395, E-mail: y-eguchi@med.uoeh-u.ac.jp 


\section{Introduction}

Recommendations for preventing lifestyle-related diseases emphasize increasing energy expenditure through exercise and daily activity. It is clear that additional physical activity and increased physical fitness provide various health related benefits [1-11]. Since busy workers often have little leisure time, raising the intensity of exercise is one suggested method for increasing energy expenditure. However, high-intensity exercise poses cardiovascular risks, may not be appropriate for the elderly or for less fit workers, and may be difficult to sustain. On the other hand, if performed safely, strenuous activity including high-intensity exercise is more beneficial to health than moderate physical activity is [9, 12-17]. If we could provide an exercise mode that combines the benefits of both high-intensity and moderate exercise, even busy workers with tight schedules would be able to participate in healthy, effective exercise regimens.

Interval training is a widespread type of aerobic training that alternates mild with high-intensity exercise. This is known to promote aerobic capacity more effectively than conventional continuous aerobic exercise. Several recent studies have revealed that interval training is an effective exercise for promoting not only aerobic capacity but also insulin signaling, endothelial function, blood glucose control, and improved systolic blood pressure [15, 18-21]. However, many of these interval exercise protocols involve repeated high-intensity exercise for more than 3 minutes each, which still poses cardiovascular risks for the elderly or those who are less fit (Fig. 1). Heart rate (HR) does not increase immediately in the early exercise period, even with a high-intensity load. If we use a decreased load in the short time before HR increases, we can preserve safety while nonetheless providing benefits from the stimulation of high-intensity exercise. Accordingly, we have developed a safe transitory stimulation interval exercise in which the duration of strenuous exertion is reduced to 30 -second periods of high-intensity exercise every 3 minutes (Fig. 1).

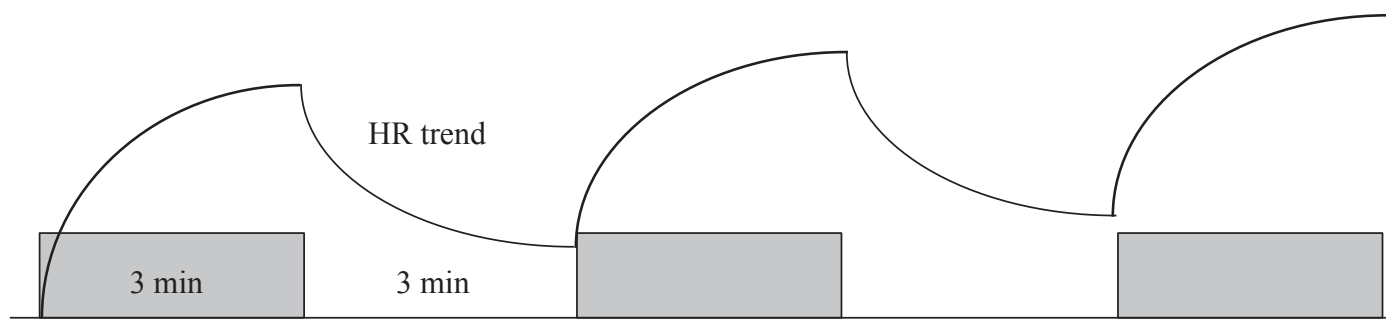

1 Strenuous load

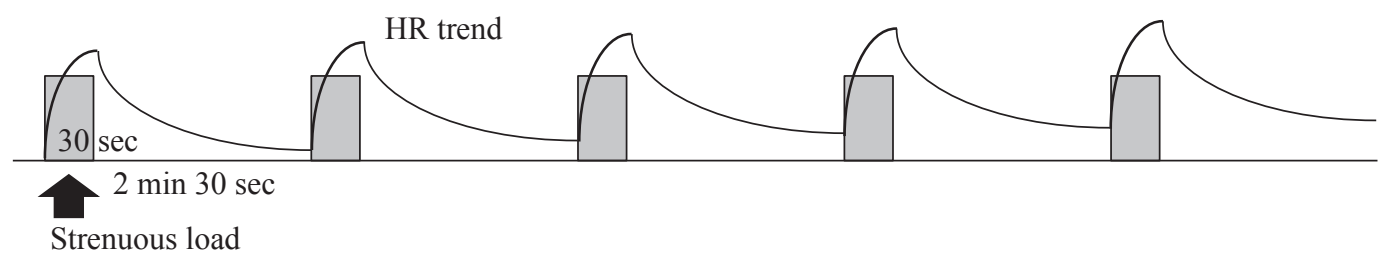

Fig. 1. Heart rate during exercise. Heart rate (HR) does not increase immediately in the early exercise period, even with a strenuous load, thus the load should be decreased a short time before the heart rate increases. 
The purpose of this study was to explore the effects of this transitory stimulation interval exercise (TSIE) on physical function compared with continuous moderate exercise (CME) involving an equivalent training volume.

\section{Methods}

\section{Study subjects}

The study subjects were recruited from the general population by means of a newspaper advertising leaflet. All subjects met the following requirements: 1 . aged 20 to 65 years; 2 . no cardiovascular disease or other contraindication to performing the exercise intervention; and 3. living within 10 minutes of a designated medical fitness club (to rule out the stress of commuting).

Thirty-eight individuals expressed interest in participating. Of these, 31 met the inclusion requirements and were enrolled in the study (Fig. 2). We excluded a male subject before the intervention because a matched control was not available. All participants provided written informed consent before the examination, and the study was approved by the ethics committee of the University of Occupational and Environmental Health.

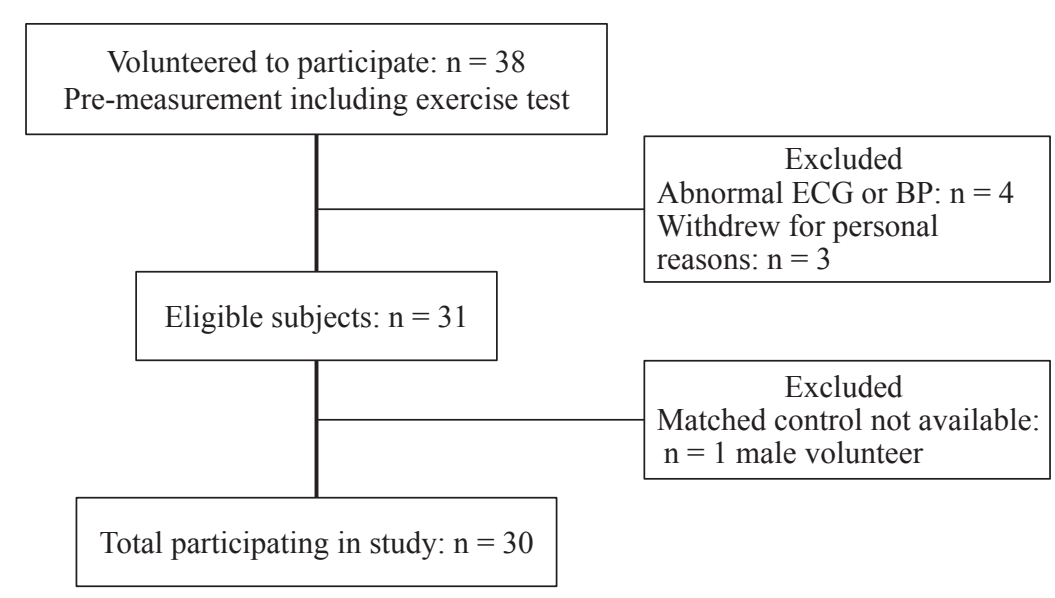

Fig. 2. Participant flow chart.

\section{Experimental design}

Between July and October 2011, 30 women between 31 and 64 years of age were randomized and stratified by age and body mass index (BMI) into a TSIE group $(\mathrm{n}=10)$, a CME group $(\mathrm{n}=$ $10)$, or a no-exercise (NE) group $(n=10)$. The two exercise groups were asked to perform endurance training using bicycle ergometers three days a week for a total of 12 weeks. For the CME group, the exercise protocol was designed to constantly maintain $50 \%$ intensity of estimated maximal oxygen uptake $\left(\dot{\mathrm{V}}_{2}\right.$ max $)$ for 30 minutes. To equalize the training volumes in the two groups, the TSIE group was asked to exercise for 2 minutes and 30 seconds at $45 \%$ of $\dot{\mathrm{V}}_{2}$ max before per- 
forming exercise for 30 -second intervals at $75 \%$ of $\dot{\mathrm{V}}_{2} \max$ for 30 minutes (Fig. 3). The bicycle ergometer loads (W) of $45 \%$ and $75 \%$ were automatically controlled for the protocol of TSIE and the subjects' fitness. The subjects needed only to press a number for the load pattern on the bicycle. We asked participants not to change any other lifestyle factors such as food intake or daily physical activity other than participating in the exercise intervention. In addition, participants were asked to wear an accelerometer to record their daily physical activity.

The participants in the exercise groups implemented the exercise intervention voluntarily at a private medical fitness club, but did not participate in any additional exercise classes or use any exercise equipment other than the bicycle ergometer. To maintain adherence to the intervention, we sent email messages or letters of encouragement to all participants once or twice a week.

\section{Measurements}

We assessed estimated $\dot{\mathrm{V}}_{2}$ max, anthropometric measurements (height, weight, body fat percentage, and waist circumference), blood pressure, biochemical data, and questionnaire data on lifestyle and food intake at baseline and after 12 weeks of the intervention. Estimated values for $\dot{\mathrm{V}}_{2}$ max were obtained using a ramp protocol exercise test (ML1800 Fukuda Denshi, Tokyo, Japan) on the bicycle ergometer. After a 2-minute warm-up period at $10 \mathrm{~W}$, the workload was increased by $5 \mathrm{~W} / \mathrm{min}$ to maintain a pedal cadence of $50 \mathrm{rpm}$ until exhaustion. The end points were identified when one of the following occurred: 1. the rating of perceived exertion (Borg's scale) reached $18 ; 2$. pedaling cadence could not be kept at 40 rpm or more; or 3. established criteria for the end of the test were met [22].

To maintain safety, the participants' electrocardiography (ECG) and blood pressure (BP) were monitored by a physician before the exercise test, throughout the test, and in the post-test recovery period.

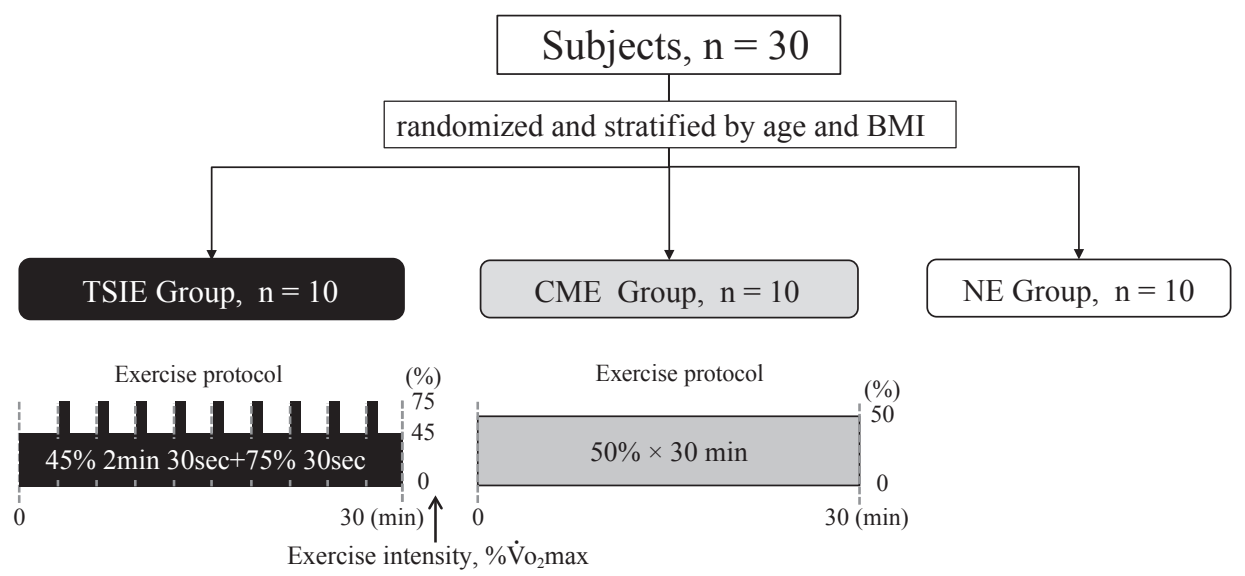

Fig. 3. Randomization and the study intervention. CME: continuous moderate exercise, TSIE: transitory stimulation interval exercise, NE: no exercise, The NE group was asked not to exercise, the two exercise groups were asked to perform endurance training using ergometers three days a week for a total of 12 weeks. 
We calculated estimated values for $\dot{\mathrm{V}}_{2}$ max by using the following formula recommended by the American College of Sports Medicine (ACSM) [23]: $\dot{\mathrm{V}}_{2} \max =1.8 \times$ peak workload $(\mathrm{W}) \times 6.12 /$ weight +7.0 .

First, we calculated the regression line by the least squares method using several HRs and workloads in the exercise test. Then, to calculate max HR, we subtracted each subject's age from 220, and calculated peak workload (W) by regression by applying this max HR. Finally, we derived the estimated $\dot{\mathrm{V}}_{2}$ max value from the peak workload and body weight by using the above formula.

Percent body fat was determined by measuring body impedance with the subjects standing on a body fat analyzer (DC-320, Tanita, Tokyo, Japan). Blood was sampled in the morning after fasting since $9 \mathrm{pm}$ the previous day. Blood pressure was calculated as the mean of three measurements obtained after a 5-min rest. All measurements were performed at the University of Occupational and Environmental Health.

\section{Statistical analysis}

The data were analyzed using StatView ver. 5 (SAS Institute Inc., Cary, NC, USA). Repeated measures ANOVAs were used to analyze mean changes from baseline after the 12-week intervention. We tested differences among the groups in the ratio of relative change for each value over the 12-week intervention period by analyzing interaction effects with group and trend by two-way ANOVAs and assessed by post hoc analysis (Fisher's PLSD). We used a statistical significance threshold of $P<0.05$. In the main analysis, we included the data of all of the participants in the NE group and the data of the participants in the exercise groups who completed more than two-thirds of the target number of exercises.

\section{Results}

There were no significant differences between groups in the baseline characteristics (Table 1). No changes in lifestyle or dietary intake throughout the intervention were observed in the questionnaire or by the accelerometer data. Estimated mean daily energy expenditure during the intervention, as determined by basal metabolism and physical activity obtained by accelerometer, was $1813 \pm 194$ $\mathrm{kcal}$ in the TSIE group, $1770 \pm 156 \mathrm{kcal}$ in the CME group, and $1762 \pm 249 \mathrm{kcal}$ in the NE group.

Table 1. Baseline characteristics of the study population

\begin{tabular}{lcrrr}
\hline Measurements & $\begin{array}{c}\text { TSIE group } \\
\mathrm{n}=10\end{array}$ & $\begin{array}{c}\text { CME group } \\
\mathrm{n}=10\end{array}$ & $\begin{array}{c}\text { NE group } \\
\mathrm{n}=10\end{array}$ & \multicolumn{1}{c}{$\begin{array}{c}\text { Total } \\
\mathrm{n}=30\end{array}$} \\
\hline Age (years) & $50.8 \pm 11.2$ & $50.7 \pm 6.5$ & $52.9 \pm 9.7$ & $51.5 \pm 9.1$ \\
Height $(\mathrm{cm})$ & $158.2 \pm 5.4$ & $156.8 \pm 2.3$ & $155.7 \pm 7.4$ & $156.9 \pm 5.4$ \\
Weight $(\mathrm{kg})$ & $62.9 \pm 10.7$ & $61.5 \pm 9.8$ & $62.0 \pm 13.8$ & $62.2 \pm 11.2$ \\
BMI $\left(\mathrm{kg} / \mathrm{m}^{2}\right)$ & $25.1 \pm 3.7$ & $25.0 \pm 3.7$ & $25.4 \pm 4.6$ & $25.1 \pm 3.9$ \\
\hline
\end{tabular}

Values: Mean \pm SD, TSIE: Transitory stimulation interval exercise, CME: continuous moderate exercise, NE: No exercise 
Table 2 shows the mean values for measurements at baseline and 12 weeks in each group. Mean weight did not decrease significantly in either of the exercise groups over the 12-week intervention period. Mean weight did not change significantly in the NE group. The results were similar for BMI and percent body fat. Systolic blood pressure decreased significantly $(P<0.01)$ in both exercise groups, as did diastolic blood pressure $(P<0.05) . \quad \dot{\mathrm{V}}_{2} \mathrm{max} /$ weight involving peak workload increased significantly in both exercise groups $(P<0.01)$. Significant decreases in HbA1c were observed in the CME group $(P<0.05)$ but not in the TSIE group. Significant decreases in total

Table 2. Measurements made at baseline and after 12 weeks

\begin{tabular}{|c|c|c|c|c|}
\hline Measurements & & $\begin{array}{l}\text { TSIE group } \\
\mathrm{n}=10\end{array}$ & $\begin{array}{c}\text { CME group } \\
n=8\end{array}$ & $\begin{array}{l}\text { NE group } \\
\mathrm{n}=10\end{array}$ \\
\hline Weight (kg) & $\begin{array}{l}\text { pre } \\
\text { post }\end{array}$ & $\begin{array}{r}62.9 \pm 10.7 \\
61.6 \pm 9.6\end{array}$ & $\begin{array}{r}62.0 \pm 10.6 \\
61.1 \pm 8.6\end{array}$ & $\begin{array}{l}62.0 \pm 13.8 \\
62.9 \pm 14.5\end{array}$ \\
\hline BMI $\left(\mathrm{kg} / \mathrm{m}^{2}\right)$ & $\begin{array}{l}\text { pre } \\
\text { post }\end{array}$ & $\begin{array}{l}25.1 \pm 3.7 \\
24.6 \pm 3.3\end{array}$ & $\begin{array}{l}25.0 \pm \\
24.6 \pm\end{array}$ & $\begin{array}{l}25.4 \pm 4.6 \\
25.7 \pm 4.8\end{array}$ \\
\hline Body fat (\%) & $\begin{array}{l}\text { pre } \\
\text { post }\end{array}$ & $\begin{array}{l}35.9 \pm 6.1 \\
35.4 \pm \quad 5.2\end{array}$ & $\begin{array}{l}36.4 \pm 5.6 \\
36.1 \pm 5.8\end{array}$ & $\begin{array}{l}36.7 \pm 5.9 \\
38.0 \pm 6.9\end{array}$ \\
\hline $\mathrm{SBP}(\mathrm{mmHg})$ & $\begin{array}{l}\text { pre } \\
\text { post }\end{array}$ & $\begin{array}{l}126.5 \pm 21.9 \\
116.5 \pm 19.5 * *\end{array}$ & $\begin{array}{l}123.8 \pm 21.7 \\
113.3 \pm 17.7 * *\end{array}$ & $\begin{array}{l}128.1 \pm 21.2 \\
122.3 \pm 15.7\end{array}$ \\
\hline DBP (mmHg) & $\begin{array}{l}\text { pre } \\
\text { post }\end{array}$ & $\begin{array}{l}78.4 \pm 12.7 \\
73.4 \pm 11.9 *\end{array}$ & $\begin{array}{l}78.1 \pm 11.2 \\
73.1 \pm 9.5 *\end{array}$ & $\begin{array}{l}78.1 \pm 12.9 \\
74.1 \pm 10.3\end{array}$ \\
\hline $\begin{array}{l}\dot{\mathrm{V}_{2}} \max / \text { Weight } \\
(\mathrm{ml} / \mathrm{kg} / \mathrm{min})\end{array}$ & $\begin{array}{l}\text { pre } \\
\text { post }\end{array}$ & $\begin{array}{l}23.4 \pm \\
25.9 \pm\end{array}$ & $\begin{array}{l}23.0 \pm \\
25.3 \pm\end{array}$ & $\begin{array}{l}22.5 \pm 3.7 \\
22.4 \pm 4.5\end{array}$ \\
\hline $\begin{array}{l}\dot{\mathrm{V}}_{2} \max \\
(l / \mathrm{min})\end{array}$ & $\begin{array}{l}\text { pre } \\
\text { post }\end{array}$ & $\begin{array}{l}1.47 \pm 0.31 \\
1.59 \pm 0.23 *\end{array}$ & $\begin{array}{l}1.42 \pm 0.26 \\
1.53 \pm 0.26 *\end{array}$ & $\begin{array}{l}1.37 \pm 0.25 \\
1.39 \pm 0.30\end{array}$ \\
\hline Peak workload (W) & $\begin{array}{l}\text { pre } \\
\text { post }\end{array}$ & $\begin{aligned} 93.4 & \pm 23.9 \\
104.8 & \pm 17.0 * *\end{aligned}$ & $\begin{aligned} 89.9 & \pm 18.8 \\
100.5 & \pm 20.7 * *\end{aligned}$ & $\begin{array}{l}84.8 \pm 17.2 \\
85.6 \pm 22.2\end{array}$ \\
\hline $\mathrm{FPG}(\mathrm{mg} / \mathrm{d} l)$ & $\begin{array}{l}\text { pre } \\
\text { post }\end{array}$ & $\begin{array}{l}99.1 \pm 5.8 \\
98.5 \pm 5.2\end{array}$ & $\begin{array}{l}96.9 \pm 8.2 \\
97.6 \pm 10.5\end{array}$ & $\begin{array}{r}99.7 \pm 10.2 \\
97.8 \pm 9.6\end{array}$ \\
\hline HbAlc $(\%)$ & $\begin{array}{l}\text { pre } \\
\text { post }\end{array}$ & $\begin{array}{l}5.32 \pm 0.36 \\
5.21 \pm 0.26\end{array}$ & $\begin{array}{l}5.33 \pm 0.30 \\
5.21 \pm 0.30 *\end{array}$ & $\begin{array}{l}5.16 \pm 0.43 \\
5.19 \pm 0.46\end{array}$ \\
\hline T-cho $(\mathrm{mg} / \mathrm{d} l)$ & $\begin{array}{l}\text { pre } \\
\text { post }\end{array}$ & $\begin{array}{l}206.6 \pm 27.8 \\
203.8 \pm 24.8\end{array}$ & $\begin{array}{l}225.4 \pm 21.1 \\
214.3 \pm 26.9 *\end{array}$ & $\begin{array}{l}219.3 \pm 30.4 \\
218.4 \pm 34.3\end{array}$ \\
\hline $\operatorname{LDL}(\mathrm{mg} / \mathrm{d} l)$ & $\begin{array}{l}\text { pre } \\
\text { post }\end{array}$ & $\begin{array}{l}126.6 \pm 35.6 \\
117.0 \pm 28.3\end{array}$ & $\begin{array}{l}128.9 \pm 33.1 \\
124.0 \pm 25.5\end{array}$ & $\begin{array}{l}130.7 \pm 19.0 \\
128.6 \pm 25.8\end{array}$ \\
\hline $\operatorname{HDL}(\mathrm{mg} / \mathrm{d} l)$ & $\begin{array}{l}\text { pre } \\
\text { post }\end{array}$ & $\begin{array}{l}55.9 \pm 10.6 \\
53.0 \pm \quad 9.9 * *\end{array}$ & $\begin{array}{l}62.1 \pm 16.8 \\
58.5 \pm 11.8\end{array}$ & $\begin{array}{r}64.5 \pm 11.9 \\
62.3 \pm 8.5\end{array}$ \\
\hline $\mathrm{TG}(\mathrm{mg} / \mathrm{d} l) \S$ & $\begin{array}{l}\text { pre } \\
\text { post }\end{array}$ & $\begin{array}{l}158.8 \pm 216.5 \\
189.4 \pm 264.7\end{array}$ & $\begin{array}{r}206.1 \pm 244.4 \\
135.0 \pm 92.0\end{array}$ & $\begin{array}{l}130.4 \pm 84.5 \\
132.1 \pm 77.0\end{array}$ \\
\hline
\end{tabular}

Values: Mean $\pm \mathrm{SD}, * *: P<0.01, *: P<0.05$ significant differences between pre- and post-intervention measurements in each group (repeated measures ANOVAs), $\dot{\mathrm{V}}_{2}$ max mean estimated values for $\dot{\mathrm{V}}_{2}$ max calculated from peak workload, Note: Participants in the exercise groups were included in the analysis if they completed more than two-thirds of the targeted amount of exercise, $\S$ : We found TG values substantially higher than $700 \mathrm{mg} / \mathrm{d} l$ for one person in the CME group at pre-intervention and for another person in the TSIE group at both pre- and post-intervention, These data should be taken into account 
cholesterol (T-cho) were observed in the CME group $(P<0.05)$ but not in the TSIE group. A significant decrease in HDL cholesterol (HDL-cho) was observed in the TSIE group $(P<0.01)$.

Table 3 shows the relative change ratios through the 12 -week exercise intervention for each group, along with the statistical significance of the differences among groups. While a significant difference in the relative change ratio between the TSIE group and the NE group was observed in decreasing body weight $(P<0.05)$, no significant difference was observed between the CME group and the NE group. The same results were observed in the relative ratio of decreased BMI $(P<0.01)$. The average ratio of increased $\dot{\mathrm{V}}_{2}$ max/weight in the TSIE group was $11.5 \%$, which was significantly different from the NE group $(P<0.05)$. There was also a significant difference in the ratio of decreased $\mathrm{HbA} 1 \mathrm{c}$ between the $\mathrm{CME}$ group and the NE group $(P<0.01)$ and between the TSIE group and the NE group $(P<0.05)$. Overall, there were few significant differences between the CME group and the TSIE group in the present study. Regarding changes in TG, there were significant differences in the CME group compared to both the TSIE and the NE groups.

Adherence to the exercise intervention throughout the 12 weeks was better in the TSIE group than in the CME group. The p-value for the difference between groups was 0.067 when the analysis included data for all participants rather than analyzing data only for those who completed more than two-thirds of the intervention.

Table 3. Comparison of relative change ratios among the groups

\begin{tabular}{lrrrrrr}
\hline Measurements (\%) & \multicolumn{2}{c}{$\begin{array}{c}\text { TSIE group } \\
\mathrm{n}=10\end{array}$} & \multicolumn{2}{c}{$\begin{array}{c}\text { CME group } \\
\mathrm{n}=8\end{array}$} & \multicolumn{1}{c}{$\begin{array}{c}\text { NE group } \\
\mathrm{n}=10\end{array}$} & \\
\hline Weight & $98.2 \pm$ & 3.2 & $98.8 \pm$ & 3.7 & $101.4 \pm 2.1$ & $\mathrm{~b}^{*}$ \\
BMI & $98.2 \pm$ & 3.1 & $98.8 \pm$ & 3.7 & $101.4 \pm 2.1$ & $\mathrm{~b}^{* *}$ \\
Body fat & $99.1 \pm$ & 4.4 & $99.1 \pm$ & 3.8 & $101.4 \pm 2.5$ & \\
SBP & $92.4 \pm$ & 7.2 & $91.9 \pm$ & 5.6 & $96.5 \pm 10.4$ & \\
DBP & $93.8 \pm$ & 6.3 & $93.9 \pm$ & 5.8 & $95.7 \pm 8.4$ & \\
$\dot{V}_{\mathrm{o}_{2} \max / \text { Weight }}$ & $111.5 \pm$ & 8.8 & $109.6 \pm$ & 7.1 & $100.0 \pm 13.2$ & $\mathrm{~b}^{*}$ \\
$\dot{V}_{\mathrm{o}_{2} \max }$ & $109.5 \pm$ & 10.0 & $108.2 \pm$ & 6.6 & $101.2 \pm 12.4$ & \\
Peak workload & $115.1 \pm$ & 14.4 & $112.5 \pm 10.4$ & $101.3 \pm 18.8$ & \\
FPG & $99.5 \pm$ & 5.4 & $100.7 \pm$ & 5.0 & $98.2 \pm 4.7$ & \\
HbAlc & $98.0 \pm$ & 3.2 & $97.9 \pm$ & 1.9 & $100.5 \pm 1.3$ & $\mathrm{~b}^{*}, \mathrm{c}^{* *}$ \\
T-cho & $99.0 \pm$ & 7.0 & $94.9 \pm$ & 6.1 & $99.6 \pm 8.3$ & \\
LDL & $94.4 \pm$ & 12.6 & $99 \pm 18.9$ & $98.0 \pm 9.9$ & \\
HDL & $94.9 \pm$ & 4.1 & $96.5 \pm 11.9$ & $100.8 \pm 9.5$ & \\
TG & $120.7 \pm$ & 36.1 & $82.7 \pm 25.0$ & $106.5 \pm 23.7$ & $\mathrm{a}^{*}, \mathrm{c}^{*}, \S$ \\
\hline
\end{tabular}

Values: Mean $\pm \mathrm{SD}$, After adjusting pre-intervention values to $100 \%$, the relative change ratio of each value over the 12-week study period was calculated, **: $P<0.01, *: P<0.05$ significant differences between groups analyzed by interaction effects, a: TSIE vs. CME, b: TSIE vs. NE, c: CME vs. NE, $\dot{V}_{2}$ max mean estimated values for $\dot{V}_{\mathrm{o}_{2}} \mathrm{max}$ calculated from peak workload, Note: Participants in the exercise groups were included in the analysis if they completed more than two-thirds of the targeted amount of exercise, §: We found TG values substantially higher than $700 \mathrm{mg} / \mathrm{d} l$ for one person in the CME group at pre-intervention and for another person in the TSIE group at both pre- and postintervention, These data should be taken into account 


\section{Discussion}

We developed a new mode of interval exercise (TSIE) that involves shorter high-intensity intervals than have been used in previous interval exercise studies. It is well known that light- to moderate-intensity physical activity has many health benefits [2-11]. In contrast, high-intensity exercises are generally not strongly recommended for the elderly or people who are less fit for reasons of safety. However, higher intensity exercise can consume more energy in a given period of time, and strenuous physical activity including high-intensity exercise provides various health benefits [7, 9, 12-17]. High-intensity exercise is beneficial for promoting good health as long as safety is ensured. Recently, interval exercises, which alternate mild and high-intensity exercises, have gradually emerged. The present study assessed whether 30 seconds of transitory stimulation is enough to change physical functioning.

There is also a dose-response relationship between the amount of exercise volume and the risk of obesity or coronary heart disease [2, 3, 6, 8-10, 24-26]. It is thought that conventional interval training increases energy expenditure compared to continuous moderate exercise, due to the higher intensity exercise intervals. Conditions having higher energy expenditures deliver great effects naturally. Therefore, to compare interval and continuous moderate exercise, we need to equate the total exercise volume. To regulate equal energy expenditures with aerobic exercise of $50 \%$ $\dot{\mathrm{V}}_{2} \max$ (the generally recommended level), we reduced the intensity of the basic aerobic level to $45 \% \dot{\mathrm{V}}_{2} \max$ and modified the intensity and time of interval stimulations to $75 \% \dot{\mathrm{V}}_{2} \max$ for 30 seconds (Fig. 3). In another unpublished pilot study of 5 healthy men (39.4 \pm 10.8 years of age), we did not observe dispersion in HR over $10 \mathrm{bpm}$ even in high intensity intervals throughout 30 minutes in the TSIE. If we had extended the stimulation intervals to 1 minute, heart rates would not have been maintained at a moderate level but would have gradually increased.

In this study, we hypothesized that TSIE would promote aerobic capacity and decrease blood pressure and blood glucose levels to a greater extent than CME, although the decrease in body fat or body weight would be similar to CME (due to comparable energy expenditures). With respect to changes resulting from the intervention, aerobic capacity increased and blood pressure decreased significantly for the TSIE group. However, nearly identical results were also observed in the CME group. In addition, HbAlc and T-cho significantly decreased only in the CME group. These results are interesting because many previous studies about conventional interval exercise showed that the health benefits were more effective compared to CME. It is unclear why HDLcho decreased only in the TSIE group. Further study is required.

On the other hand, there were significant differences in relative change ratios between the NE and TSIE groups through the 12-week intervention: the TSIE group showed positive effects in weight loss, $\mathrm{HbAlc}$, and $\dot{\mathrm{Vo}}_{2} \max /$ weight, even though the stimulation was only transitory. Significant differences in relative change ratios were also observed in the CME group compared to the NE group, with positive effects on HbA1c and TG.

The characteristic tendencies of change in the TSIE group relative to the NE group were somewhat different from comparisons between the CME and NE groups. Despite few significant differences between the TSIE group and CME group, we can refer to these results as a pilot study. 
Overall, the results of this study do not indicate that TSIE is more effective than CME in generating health benefits. Even if TSIE did stimulate some health related functions, there would be no differences in metabolic functions between TSIE and CME in a long term intervention with equalized training volumes.

Although only marginally significant $(P=0.067)$, our results suggest that TSIE is a more sustainable exercise regimen than the CME approach for a 12-week intervention. Moreover, all the participants in the TSIE group almost perfectly completed the prescribed number of exercise times, which is a rare case in long-term interventions. These results are important because unsustainable programs lead to the failure to gain health benefits.

\section{Study limitation}

We found one person in the CME group with a pre-intervention TG value substantially higher than $700 \mathrm{mg} / \mathrm{d} l$, and another person in the TSIE group with a TG value higher than $700 \mathrm{mg} / \mathrm{d} l$ at both pre- and post-intervention. These elevated levels may require special consideration and perhaps should have been excluded from the current assessment. A second limitation is that we studied an all-female population with a small number of participants; however, we did not have the resources to conduct a larger study in our institution. The small sample size may have limited our ability to detect significant differences between groups, especially as there were some extreme values in some of the measurements. The total weekly exercise period of 90 minutes may also be inadequate, especially for participants seeking to lose weight. However, this level of exercise may also be a more realistic commitment for working people, particularly in Japan, and thus, exercise adherence with this approach might be better.

\section{Conclusion}

We developed a new mode of interval exercise (TSIE) that involves shorter high-intensity intervals than have been used in previous interval exercise studies.

Although we observed a greater benefit for physical function in several health-related measurements in the TSIE group compared to the NE control group, we did not observe significant differences between the TSIE and CME groups. This result may have been caused by the small sample size or the long term equalized training volume between both exercise groups. There might not be any differences in metabolic functions. The results of the present study could provide some implications for future studies that could develop another, more effective interval exercise pattern with health benefits for the elderly or less fit persons. Nonetheless, further study with a larger population is required.

\section{Acknowledgements}

This work was supported by The Ministry of Education, Culture, Sports, Science and Technology Grant-in-Aid for Scientific Research (23500830). We would like to thank Tomoyo Omae for collecting measurements and the staff of Suikokai Total Rehab and Fitness Center for their cooperation in this study. 


\section{References}

1. American College of Sports Medicine) (ACSM) (2009): Benefits and risks associated with physical activity. In: ACSM's Guidelines for Exercise Testing and Prescription, 8th. Wolters Kluwer/Lippincott Williams \& Wilkins, Philadelphia pp 2-9

2. Kesaniemi YA, Danforth E Jr, Jensen MD, Kopelman PG, Lefèbvre P \& Reeder BA (2001): Dose-response issues concerning physical activity and health: an evidence-based symposium. Med Sci Sports Exerc 33(6 suppl): S351-S358

3. Ferrucci L, Izmirlian G, Leveille S, Phillips CL, Corti MC, Brock DB \& Guralnik JM (1999): Smoking, physical activity, and active life expectancy. Am J Epidemiol 149: 645-653

4. Feskanich D, Willett $\mathrm{W} \&$ Colditz G (2002): Walking and leisure-time activity and risk of hip fracture in postmenopausal women. JAMA 288: 2300-2306

5. Hu FB, Sigal RJ, Rich-Edwards JW, Colditz GA, Solomon CG, Willett WC, Speizer FE \& Manson JE (1999): Walking compared with vigorous physical activity and risk of type 2 diabetes in women - a prospective study. JAMA 282: 1433-1439

6. Lee IM, Rexrode KM, Cook NR, Manson JE \& Buring JE (2001): Physical activity and coronary heart disease in women - Is "no pain, no gain" passé? JAMA 285: 1447-1454

7. Manson JE, Greenland P, LaCroix AZ, Stefanick ML, Mouton CP, Oberman A, Perri MG, Sheps DS, Pettinger MB\& Siscovick DS (2002): Walking compared with vigorous exercise for the prevention of cardiovascular events in women. New Engl J Med 347: 716-725

8. Rockhill B, Willett WC, Manson JE, Leitzmann MF, Stampfer MJ, Hunter DJ \& Colditz GA (2001): Physical activity and mortality: a prospective study among women. Am J Public Health 91: 578-583

9. Tanasescu M, Leitzmann MF, Rimm EB, Willett WC, Stampfer MJ \& Hu FB (2002): Exercise type and intensity in relation to coronary heart disease in men. JAMA 288: 1994-2000

10. Yu S, Yarnell JW, Sweetnam PM\& Murray L (2003): What level of physical activity protects against premature cardiovascular death? The Caerphilly study. Heart 89: 502-506

11. Williams PT (2001): Physical fitness and activity as separate heart disease risk factors: a meta-analysis. Med Sci Sports Exerc 33: 754-761

12. Bernaards CM, Jans MP, van den Heuvel SG, Hendriksen IJ, Houtman IL \& Bongers PM (2006): Can strenuous leisure time physical activity prevent psychological complaints in a working population? Occup Environ Med 63: 10-16

13. Hunter GR, Weinsier RL, Bamman MM\&Larson DE (1998): A role for high intensity exercise on energy balance and weight control. Int J Obes Relat Metab Disord 22: 489-493

14. Johnson JL, Slentz CA, Houmard JA, Samsa GP, Duscha BD, Aiken LB, McCartney JS, Tanner CJ \& Kraus WE (2007): Exercise training amount and intensity effects on metabolic syndrome (from Studies of a Targeted Risk Reduction Intervention through Defined Exercise). Am J Cardiol 100: 17591766

15. Nybo L, Sundstrup E, Jakobsen MD et al (2010): High-intensity training versus traditional exercise interventions for promoting health. Med Sci Sports Exerc 42: 1951-1958

16. Schjerve IE, Tyldum GA, Tjønna AE et al (2008): Both aerobic endurance and strength training programmes improve cardiovascular health in obese adults. Clin Sci (Lond) 115: 283-293 
17. Weiss JP, Froelicher VF, Myers JN\& Heidenreich PA (2004): Health-care costs and exercise capacity. Chest 126: 608-613

18. Haram PM, Kemi OJ, Lee SJ et al (2009): Aerobic interval training vs continuous moderate exercise in the metabolic syndrome of rats artificially selected for low aerobic capacity. Cardiovasc Res 81: 723-732

19. Nemoto K, Gen-no H, Masuki S, Okazaki K\&Nose H (2007): Effects of high-intensity interval walking training on physical fitness and blood pressure in middle-aged and older people. Mayo Clin Proc 82: 803-811

20. Tjønna AE, Lee SJ, Rognmo Ø et al (2008): Aerobic interval training versus continuous moderate exercise as a treatment for the metabolic syndrome: a pilot study. Circulation 118: 346-354

21. Wisløff U, Støylen A, Loennechen JP et al (2007): Superior cardiovascular effect of aerobic interval training versus moderate continuous training in heart failure patients - a randomized study. Circulation 115: 3086-3094

22. Wolters Kluwer (2009): Test termination criteria. In: ACSM's guidelines for exercise testing and prescription, 8th ed. American College of Sports Medicine. (ACSM) Lippincott Williams \& Wilkins, Philadelphia pp 82-83

23. Wolters Kluwer (2009): General principles of exercise prescription. ACSM's guidelines for exercise testing and prescription, 8th ed. American College of Sports Medicine. (ACSM) Lippincott Williams \& Wilkins, Philadelphia pp 152-182

24. Haskell WL, Lee IM, Pate RR, Powell KE, Blair SN, Franklin BA, Macera CA, Heath GW, Thompson PD \& Bauman A: (2007): Physical activity and public health: updated recommendation for adults from the American College of Sports Medicine and the American Heart Association. Circulation 116: 1081-1093

25. Jakicic JM, Clark K, Coleman E, Donnelly JE, Foreyt J, Melanson E, Volek J\& Volpe SL (2001): Appropriate intervention strategies for weight loss and prevention of weight regain for adults. American college of sports medicine position stand. Med Sci Sports Exerc 33: 2145-2156

26. Saris WH, Blair SN, van Baak MA et al (2003): How much physical activity is enough to prevent unhealthy weight gain? Outcome of the IASO 1st stock conference and consensus statement. Obes Rev 4: $101-114$ 
短時間刺激型インターバル運動が身体諸機能に及ぼす効果 - 日本人における無作為 化比較介入試験によるパイロット研究 -

江口 泰正, 太田 雅規, 井上 智博, 本多 融, 守田 祐作, 今野 由将,

大和浩

産業医科大学 産業生態科学研究所 健康開発科学研究室

要 旨：インターバルトレーニングは, 有酸素能力の向上だけでなく健康に対しても効果的 である。しかしながらこのトレーニングは高強度運動を伴っており, 高齢者や低体力者には心血 管系へのリスクもある。そこで, 高強度運動の時間を短縮した短時間刺激型のインターバル運動 (Transitory Stimulation Interval Exercise: TSIE)を開発し, その効果について調査した.30名の女性を 無作為にTSIE群, 一定負荷運動 (Continuous Moderate Exercise: CME) 群, 非運動 (No-exercise: NE) 群 に割り振り, 運動群には12週間運動を継続して行った。その結果, TSIE群はNE群と比較して体重減 少率と有酸素能力向上率において有意な効果が見られたが, CME群とNE群との間には有意な差は 認められなかった. HbA1c低下については, TSIE, CME両群ともにNE群と比較して有意な効果が見 られた。しかしながら全体的にはTSIE群とCME群との間にはほとんど有意な差は認められなかっ た。エネルギー消費量が同等なため, 一時的な刺激にはなるが, 長期的には差が生じない可能性が ある。

キーワード : 短時間刺激, インターバル運動, 酸素摂取量, 無作為化比較試験, ヘルスプロモーション.

J UOEH（産業医大誌）34（4）：297－308（2012） 